\title{
The role of microfilaments and microtubules in apical growth and dimorphism of Candida albicans
}

\author{
Koji Yokoyama, ${ }^{*}$ Haruo KaJi, Kazuko Nishimura and Makoto MiYajI \\ Department of Fungal Infections, Research Center for Pathogenic Fungi and Microbial Toxicoses, Chiba University, \\ 1-8-1 Inohana, Chiba 280, Japan
}

(Received 25 October 1989; revised 3 January 1990; accepted 31 January 1990)

\begin{abstract}
Cytoskeleton inhibitors were used to study morphogenesis in the pathogenic and dimorphic fungus Candida albicans. Nocodazole is a specific microtubule inhibitor and chloropropham (CIPC), at high concentrations, is an inhibitor of microtubules and microfilaments. Distribution of microtubules and microfilaments was studied by immunofluorescence techniques using anti-tubulin antibody with FITC-conjugated secondary antibody, and by staining with $\mathbf{R h}$-phalloidin. Nocodazole did not arrest apical cell elongation at a concentration $\left(20 \mu \mathrm{g} \mathrm{ml}^{-1}\right)$ that inhibited nuclear division and migration. Cytoplasmic and nuclear microtubules disappeared within $\mathbf{3 0}$ min in filamentous cells under these conditions. However, the Rh-phalloidin-stained actin granules which were localized in the tips of filamentous cells, and the microfilaments, were arranged normally at this concentration of nocodazole. Growth, and normal distribution of microtubules and microfilaments, were inhibited by a high concentration $\left(200 \mu \mathrm{g} \mathrm{ml}^{-1}\right)$ of CIPC. At a concentration $\left(100 \mu \mathrm{g} \mathrm{ml}^{-1}\right)$ of CIPC that permitted nuclear division, apical cell elongation was arrested, and filamentous growth was converted into yeast growth. At this concentration of CIPC, microtubules were distributed normally in filamentous cells. Long microfilaments were not observed, and actin granules did not localize in the tips of filamentous cells, but were distributed throughout the cytoplasmic cortex. Our results show that cytoplasmic microtubules are not essential for the elongation of filamentous cell tips but that microfilaments are apparently essential for this process.
\end{abstract}

\section{Introduction}

The study of dimorphism in fungi is useful for elucidating the mechanisms of morphogenesis, growth and differentiation. Candida albicans is a pathogenic and polymorphic fungus having four major morphologies: yeasts, pseudohyphae, hyphae and chlamydospores; however, pseudohyphae and hyphae are closely allied. It has been suggested that the ability to form pseudohyphae and hyphae relates to the pathogenesis of this fungus.

There are several important differences in growth between yeast and filamentous forms of $C$. albicans. In pseudohyphae or hyphae, the mother cell has a longer generation time than the daughter cell, whereas in the yeast form the daughter cell has a longer unbudded period than the mother cell (Yokoyama \& Takeo, 1983). These differences are due to differences of asymmetrical divisions between the yeast and pseudohyphal forms (Yokoyama \& Takeo, 1983).

Abbreviations: CIPC, isopropyl ( $N$-(3-chlorophenyl))carbamate (chloropropham); DAPI, 4',6-diamidino-2-phenylindole; FITC, fluorescein isothiocyanate; $\mathrm{Rh}$-phalloidin, tetramethylrhodaminyl phalloidin.
Microtubules and/or microfilaments have been observed using immunofluorescence and cytochemical labelling in Saccharomyces cerevisiae (Jacobs et al., 1988; Kilmartin \& Adams, 1984), Saccharomyces uvarum (Kilmartin \& Adams, 1984), Schizosaccharomyces pombe (Marks et al., 1986; Hagan \& Hyams, 1988), Candida albicans (Barton \& Gull, 1988), Neurospora crassa (Caesar et al., 1988) and Uromyces phaseoli (Hoch \& Staples, 1985). Various reports have shown that microtubules are important in tip growth or morphogenesis in fungi: in Fusarium acuminatum (Howard \& Aist, 1980), Neurospora crassa (That et al., 1988), Physcomitrella patens (Doonan et al., 1988) and Schizosaccharomyces pombe (Hagan \& Hyams, 1988). It has also been reported that cytoplasmic microtubules are apparently not essential for the establishment of cell polarity and localization of cellsurface growth in Saccharomyces cerevisiae (Jacobs et al., 1988). Byers \& Goetsch (1975) showed that microtubules play an important role in nuclear division of Saccharomyces cerevisiae.

Immunofluorescent and fluorochrome-labelled phalloidin staining has shown that actin is localized at the sites of budding in Saccharomyces uvarum and $S$. 
cerevisiae (Kilmartin \& Adams, 1984; Adams \& Pringle, 1984). These observations, and studies of mutant strains with defects in the essential actin structural gene of $S$. cerevisiae (Novick \& Botstein, 1985), suggest that actin localization plays an important role in yeast cell wall deposition and growth. In $C$. albicans, a distinct difference was demonstrated in localization of actin in growing buds and hyphae, and this was thought to relate to differences in the expansion zones of the cell walls Anderson \& Soll (1986).

In this report, it is demonstrated that microfilaments (actin filaments) are important in apical cell elongation of hyphae and dimorphism in $\dot{C}$. albicans, and that the cytoplasmic microtubules are not essential for apical cell elongation.

\section{Methods}

Organism. The Candida albicans strains used, IFM (Research Center for Pathogenic Fungi and Microbial Toxicoses) 40009 (ATCC 48130), 40100,40101 and 40102, were all clinical isolates.

Media and culture. Preincubation liquid medium was YPD, containing $1 \%(\mathrm{w} / \mathrm{v})$ yeast extract, $2 \%(\mathrm{w} / \mathrm{v})$ polypeptone and $2 \%(\mathrm{w} / \mathrm{v})$ glucose. Hypha-forming medium (HFM7) contained the following, per litre: glucose, $5 \mathrm{~g} ; \mathrm{Na}_{2} \mathrm{HPO}_{4} .12 \mathrm{H}_{2} \mathrm{O}, 0.26 \mathrm{~g} ; \mathrm{KH}_{2} \mathrm{PO}_{4}, 0.66 \mathrm{~g}$; $\mathrm{MgSO}_{4} .7 \mathrm{H}_{2} \mathrm{O}, 0.08 \mathrm{~g} ; \mathrm{NH}_{4} \mathrm{Cl}, 0.33 \mathrm{~g}$; and biotin, $16 \mu \mathrm{g}$; plus $4 \%(\mathrm{v} / \mathrm{v})$ calf serum (Gibco). The pH of HFM7 was adjusted to 7.0 with $3 \mathrm{M}-$ $\mathrm{NaOH}$. HFM7 was sterilized by filtration. Cells were cultured in $30 \mathrm{~mm}$ diameter plastic Petri dishes coated with $100 \mu \mathrm{l}$ of a $100 \mu \mathrm{g} \mathrm{ml}^{-1}$ solution of poly-L-lysine (poly-L-lysine hydrobromide, $M_{\mathrm{r}} 70000$ 150000 ; Sigma). After $5 \mathrm{~min}$ the solution was removed by aspiration and the treated surface was rinsed twice with $1.5-2.0 \mathrm{ml}$ of sterile distilled and de-ionized water. The culture dishes were air-dried before use.

Inhibition of cytoskeleton. The microtubule and/or microfilament inhibitors nocodazole and chloropropham [isopropyl( $N$-(3-chlorophenyl))carbamate (CIPC)] were used. Nocodazole is a specific microtubule inhibitor. It exerts its effect in vivo and in vitro by reversibly binding to tubulin and inhibiting microtubule polymerization (De Brabander et al., 1976). It is also a competitive inhibitor of colchicine in animal cells (Hoebeke et al., 1976). CIPC, a widely used herbicide (chloropropham) affects microtubule and microfilament organization in animal cells (Oliver et al., 1978). The related compound methyl(benzimidazol-2-yl)-carbamate (MBC) inhibits microtubule function and causes mitotic arrest of Saccharomyces cerevisiae (Davidse \& Flach, 1977; Quinlan et al., 1980). Nocodazole (Aldrich) and CIPC (Sigma) were dissolved in dimethyl sulphoxide (DMSO) and then added aseptically to the medium in each experiment. The final DMSO concentration in the medium was below $0.5 \%(\mathrm{v} / \mathrm{v})$. C. albicans was preincubated in YPD medium at $27^{\circ} \mathrm{C}$ and magnetically stirred (about 120 r.p.m.). After $24-48$ h, in the early stationary phase, the cells were washed and inoculated in HFM7 in a Petri dish. Each inhibitor was added after $3.5 \mathrm{~h}$ of incubation at $37^{\circ} \mathrm{C}$.

Nuclear staining and photomicroscopy. The cultures were fixed with $3.7 \%(\mathrm{v} / \mathrm{v})$ formaldehyde for $30 \mathrm{~min}$ and washed. Nuclei were stained with 4',6-diamidino-2-phenylindole (DAPI) (200 $\mathrm{ng} \mathrm{ml}^{-1}$; Sigma). Cells were observed and photographed with an epi-illumination fluorescence microscope (Nikon SPM-RFL-II; Nippon Kogaku K.K.).
Time-lapse photomicrography. Cell growth was observed using a Nikon TMD inverted phase-contrast microscope (Nippon Kogaku K.K.). Cells were photographed at 15 min intervals.

Observation of microtubules and microfilaments. Cells were fixed for $30 \mathrm{~min}$ at $37^{\circ} \mathrm{C}$ and for $1 \mathrm{~h}$ at room temperature with $4 \%(\mathrm{w} / \mathrm{v})$ paraformaldehyde in phosphate-buffered saline (PBS) containing $5 \%$ (v/v) DMSO (5\% DMSO-PBS). PBS comprised $\mathrm{NaCl}, 0.8 \% ; \mathrm{KCl}$, $0.02 \% ; \mathrm{Na}_{2} \mathrm{HPO}_{4} .12 \mathrm{H}_{2} \mathrm{O}, 0.29 \% ; \mathrm{KH}_{2} \mathrm{PO}_{4}, 0.02 \%$; adjusted to pH 8.2 with $3 \mathrm{M}-\mathrm{NaOH}$. Fixed cells were washed twice in $5 \%$ DMSOPBS (pH 7.2). These cells were stored overnight at $8{ }^{\circ} \mathrm{C}$ for triple staining.

For observation of F-actin (microfilaments and actin granules), fixed and washed cells were incubated in a cell wall lytic enzyme solution [Zymolyase-20T (Seikagaku Kogyo Co.), 5 units $\mathrm{ml}^{-1}$, in $5 \%$ DMSOPBS pH 7.2] for $30 \mathrm{~min}$ at $27^{\circ} \mathrm{C}$. Zymolyase-treated cells were soaked in Rh-phalloidin (tetramethyl-rhodaminyl-phalloidin; Molecular Probes Inc.) solution (containing nine parts 5\% DMSO plus $0.05 \%$ Triton X-100 to one part $\mathrm{Rh}$-phalloidin) for $1.5 \mathrm{~h}$. After rinsing, the $\mathrm{Rh}-$ phalloidin-stained cells were observed and photographed with an epiillumination fluorescence microscope (Nikon SPM-RFL-II).

For triple staining, after Zymolyase treatment, the cells were washed twice in 5\% DMSO-PBS (pH 7.2) and then soaked in $0.2 \%$ Triton X100 in $5 \%$ DMSO-PBS for 10 min at room temperature. Triton X-100treated cells were washed twice and soaked in $5 \%$ DMSO-BSA-PB [ $5 \%$ DMSO and $1 \%(\mathrm{w} / \mathrm{v})$ bovine serum albumin in phosphate buffer: $\left.0.29 \% \mathrm{Na}_{2} \mathrm{HPO}_{4} \cdot 12 \mathrm{H}_{2} \mathrm{O}, 0.02 \% \mathrm{KH}_{2} \mathrm{PO}_{4}\right]$. For tubulin labelling, monoclonal anti-yeast-tubulin YOLI/34 IgG (Serotec Inc.) was added to 0.1 vol. $5 \%$ DMSO-BSA-PB and incubated for $1.5 \mathrm{~h}$ at $27^{\circ} \mathrm{C}$. After washing with $5 \%$ DMSO-BSA-PB, affinity-purified fluorescein isothiocyanate-(FITC-) conjugated anti-rat IgG was added, normally at a dilution of $1: 100$ in $5 \%$ DMSO-BSA-PB, for $1.5 \mathrm{~h}$ at $27^{\circ} \mathrm{C}$. The cells were washed with $5 \%$ DMSO-PBS and added to Rh-phalloidin solution, normally at a dilution of $1: 10$ in $0.05 \%$ Triton-X-100/5\% DMSO-PBS, for F-actin labelling. The cells were washed with $5 \%$ DMSO-PBS and stained with DAPI $\left(20 \mathrm{ng} \mathrm{ml}^{-1}\right)$. The cells in the Petri dish were observed and photographed with the epi-illumination fluorescence microscope. For rhodamine, a green $(530 \mathrm{~nm})$ excitation filter, a DM-580 dichroic mirror, a 580W suppressor filter, and an NCF Fluor $100 \times$ objective lens were used. For FITC, a blue $1(450 \mathrm{~nm})$ excitation filter, a DM-510 dichroic mirror, and a $515 \mathrm{~W}$ suppressor filter were used. For DAPI, a UV (365 nm) excitation filter, a DM-400 dichroic mirror and a 420K suppressor filter were used. Photographs were taken on Kodak Tri-X pan film. Film was developed with sensitization in Pandol (Fuji).

\section{Results}

\section{Effect of nocodazole on elongation of the apical cell tips}

C. albicans grew in YPD medium as the yeast form. When it was cultured in a serum-containing medium (HFM7) and the temperature raised from $27^{\circ} \mathrm{C}$ to $37^{\circ} \mathrm{C}$, its morphology changed from the yeast to the hyphal form: the yeast cells produced germ tubes, which were $25-50 \mu \mathrm{m}$ long after $3.5 \mathrm{~h}$ incubation. At this time there were one or two nuclei in each germling (Fig. 1a). After $3.5 \mathrm{~h}$ incubation, nocodazole was added to the culture, which was incubated for an additional $3 \mathrm{~h}$. Nuclear division was inhibited at nocodazole concentrations of 40,20 and $10 \mu \mathrm{g} \mathrm{ml}^{-1}$. However, these concentrations of 

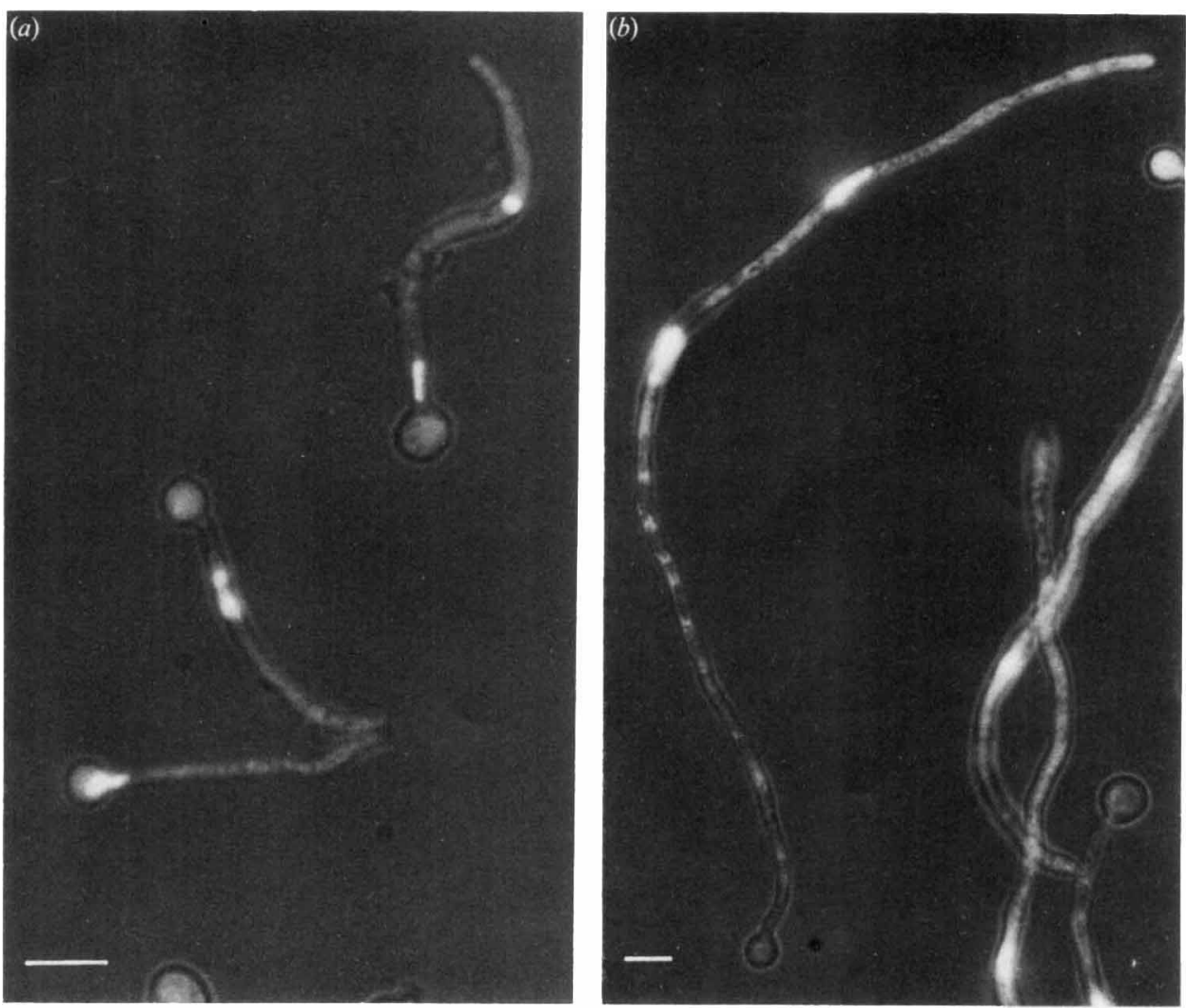

Fig. 1. Fluorescence photomicrographs of (a) control cells and (b) nocodazole-treated cells of $C$. albicans IFM 40009. (a) Cells were incubated in HFM7 for $3.5 \mathrm{~h}$ and then fixed and stained with DAPI. There were one or two nuclei in each germling. (b) Cells were incubated in HFM 7 for $3.5 \mathrm{~h}$ and then nocodazole $\left(20 \mu \mathrm{g} \mathrm{ml}^{-1}\right)$ was added. After further incubation for $3 \mathrm{~h}$ they were fixed and stained with DAPI. Nuclear division was inhibited, but elongation of the apical cell tip was not. Bars, $5 \mu \mathrm{m}$.

nocodazole did not hinder the elongation of apical cells (Fig. $1 b$ ). In the presence of nocodazole, apical cells elongated to about $80 \mu \mathrm{m}$ in length. In control cultures, generally the lengths of apical cells were about $20 \mu \mathrm{m}$ just after septation, and $40 \mu \mathrm{m}$ just before septation. Septa were not formed in apical cells in the presence of nocodazole, and lateral budding was not observed from the hyphae.

\section{Effect of nocodazole on distribution of microtubules, microfilaments and actin granules}

Microtubules were observed by use of the anti-yeast tubulin antibody and FITC-conjugated secondary IgG. In control hyphal cells (Fig. 2), cytoplasmic microtubules lay lengthwise. Apical cells, which were about twice as long as mature cells before septation, contained long microtubules running from side to side (Fig. $2 a$ ). The distribution of microtubules changed with each cell cycle, but microtubules were observed throughout the cell cycle of control hyphal cells. Microfilaments and actin granules were observed by $\mathrm{Rh}$-phalloidin staining (Fig. 2b).

In control hyphal cells, actin granules were localized at the tips of apical cells (Fig. $3 a, b$ ) and at septum-forming sites (Fig. 2b). Clusters of actin granules were also observed at lateral budding sites. A network of filamentous actin (microfilaments) was observed in the tips of apical cells, often connected to actin granules (Fig. $2 b$, $3 a, b)$. Thicker and longer actin filaments were observed along the lines of cell growth (Fig. $3 a, b$ ). On the inner surface of the cell walls there were few actin granules except at the cell tips (Fig. 2b, 3a, b). The same observations were made in nocodazole-treated cells stained with Rh-phalloidin (Fig. $4 b, 5 b, 6$ ).

When nocodazole was added $\left(10-40 \mu \mathrm{g} \mathrm{ml}^{-1}\right)$, the long cytoplasmic microtubules disappeared from the cells within $30 \mathrm{~min}$ (Fig. 4a). Rh-phalloidin-stained cells showed the same localization of actin granules and microfilaments (Fig. $4 b$ ) as observed in control cells. Nuclear division, detected by DAPI, was inhibited (Fig. $4 c$ ), but apical cell elongation continued at these concentrations of nocodazole (Fig. $1 b, 5,6$ ). 

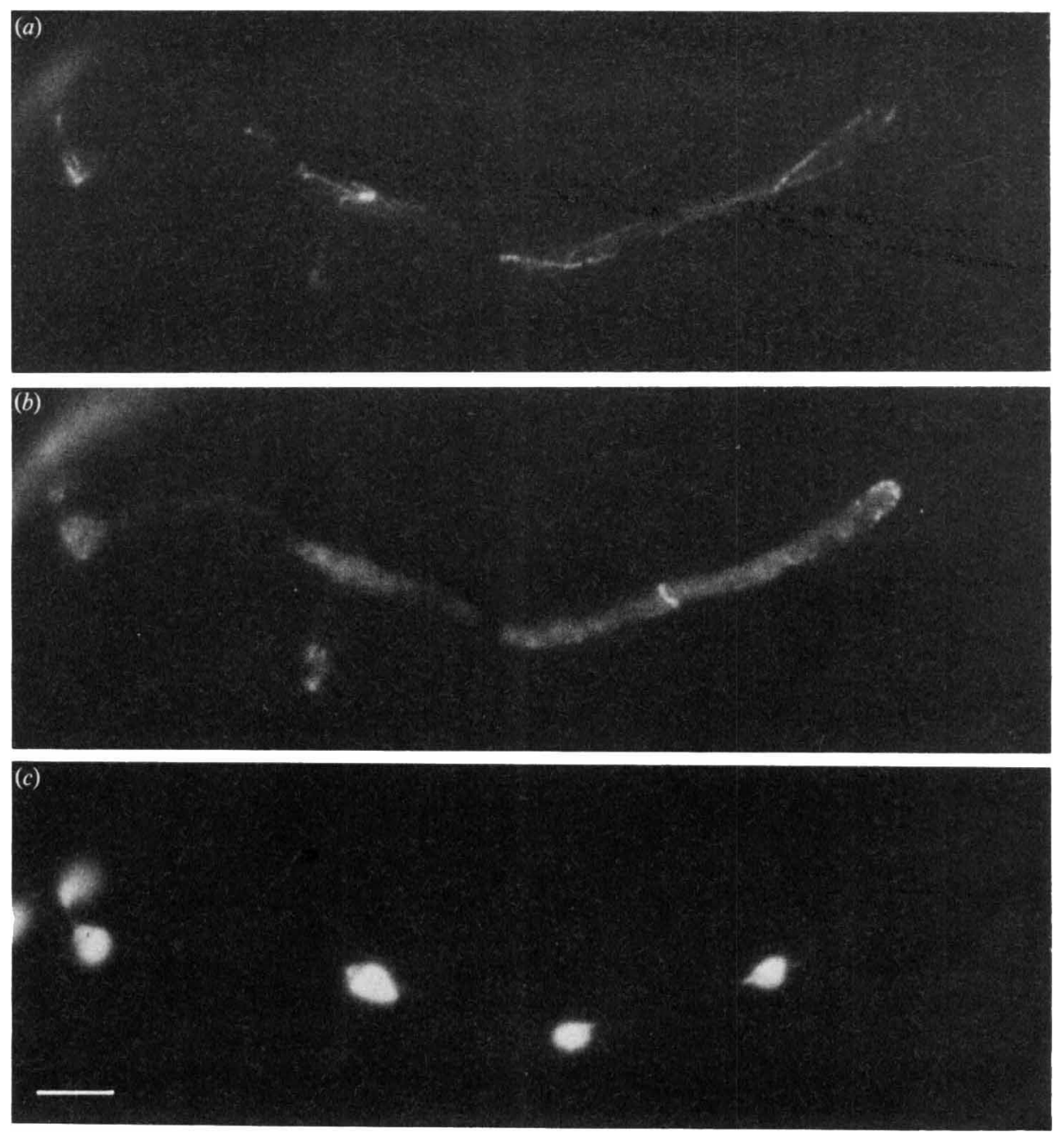

Fig. 2. Triple staining of control cells of $C$. albicans IFM 40009, showing microtubules, microfilaments and actin granules, and nuclei. Cells were incubated for $6.5 \mathrm{~h}$ in HFM7 and then fixed. (a) Staining with anti-yeast-tubulin antibody and FITC-conjugated secondary antibody, showing microtubules; $(b)$ staining with Rh-phalloidin, showing microfilaments and actin granules; $(c)$ staining with DAPI, showing nuclei. Bar, $5 \mu \mathrm{m}$.

\section{Change of growth from hyphal to yeast form induced by} CIPC

When yeast cells were incubated with CIPC at $200 \mu \mathrm{g} \mathrm{ml}^{-1}$ in HFM7 medium, cell growth stopped.

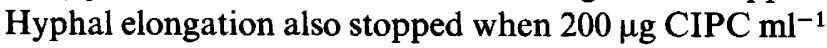
was added to HFM7 medium after $3.5 \mathrm{~h}$ of incubation.

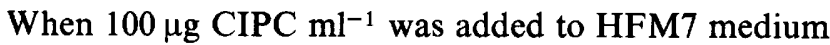
after $3.5 \mathrm{~h}$ of incubation, hyphal growth changed to yeast growth (Fig. 7). When $50 \mu \mathrm{g}$ CIPC ml-1 was added, hyphal growth continued in HFM7 medium. CIPC at $100 \mu \mathrm{g} \mathrm{ml}^{-1}$ did not inhibit growth of $C$. albicans in the yeast form. Time-lapse photomicrographs (Fig. 7) showed that mother yeast or filamentous cells formed buds sooner than apical or daughter cells when treated with $100 \mu \mathrm{g}$ CIPC $\mathrm{ml}^{-1}$. CIPC treatment produced three patterns of budding on hyphal cells. First, elongation of the apical cell was inhibited and a bud was formed at the cell tip (Fig. 8a). Second, elongation of the apical cell

Fig. 3. Rh-phalloidin staining of control cells of $C$. albicans IFM 40009, showing the location of actin granules, long microfilaments (a) and a network of microfilaments $(b)$. Bars, $5 \mu \mathrm{m}$.

Fig. 4. Triple staining of nocodazole-treated hyphal cells of $C$. albicans IFM 40009. Cells were fixed after 30 min incubation with nocodazole $\left(20 \mu \mathrm{g} \mathrm{ml}^{-1}\right)$ in HFM7 medium. (a) Staining with anti-yeast-tubulin antibody and FITC-conjugated secondary antibody; (b) staining with Rh-phalloidin; (c) staining with DAPI. Microtubules disappeared (a) but actin granules were still localized in apical cell tips (b). Bar, $5 \mu \mathrm{m}$. 

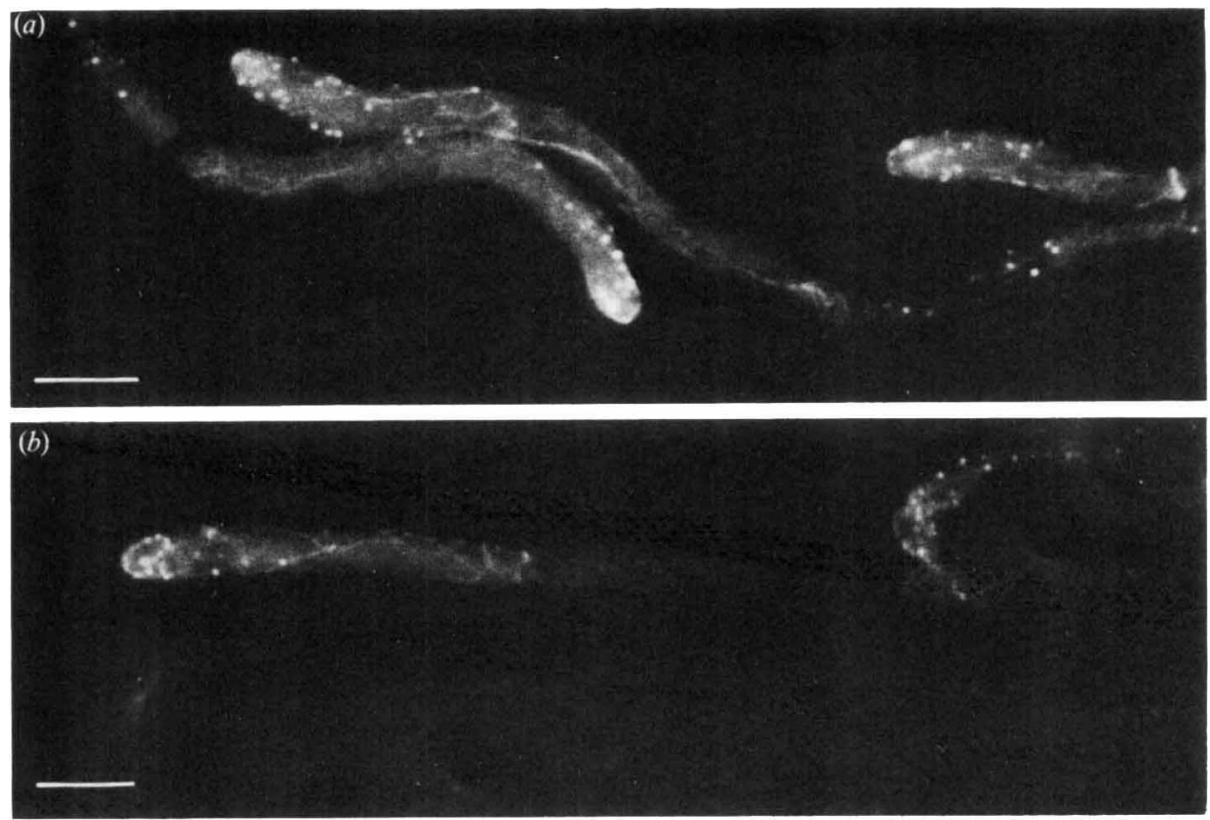

Fig. 3
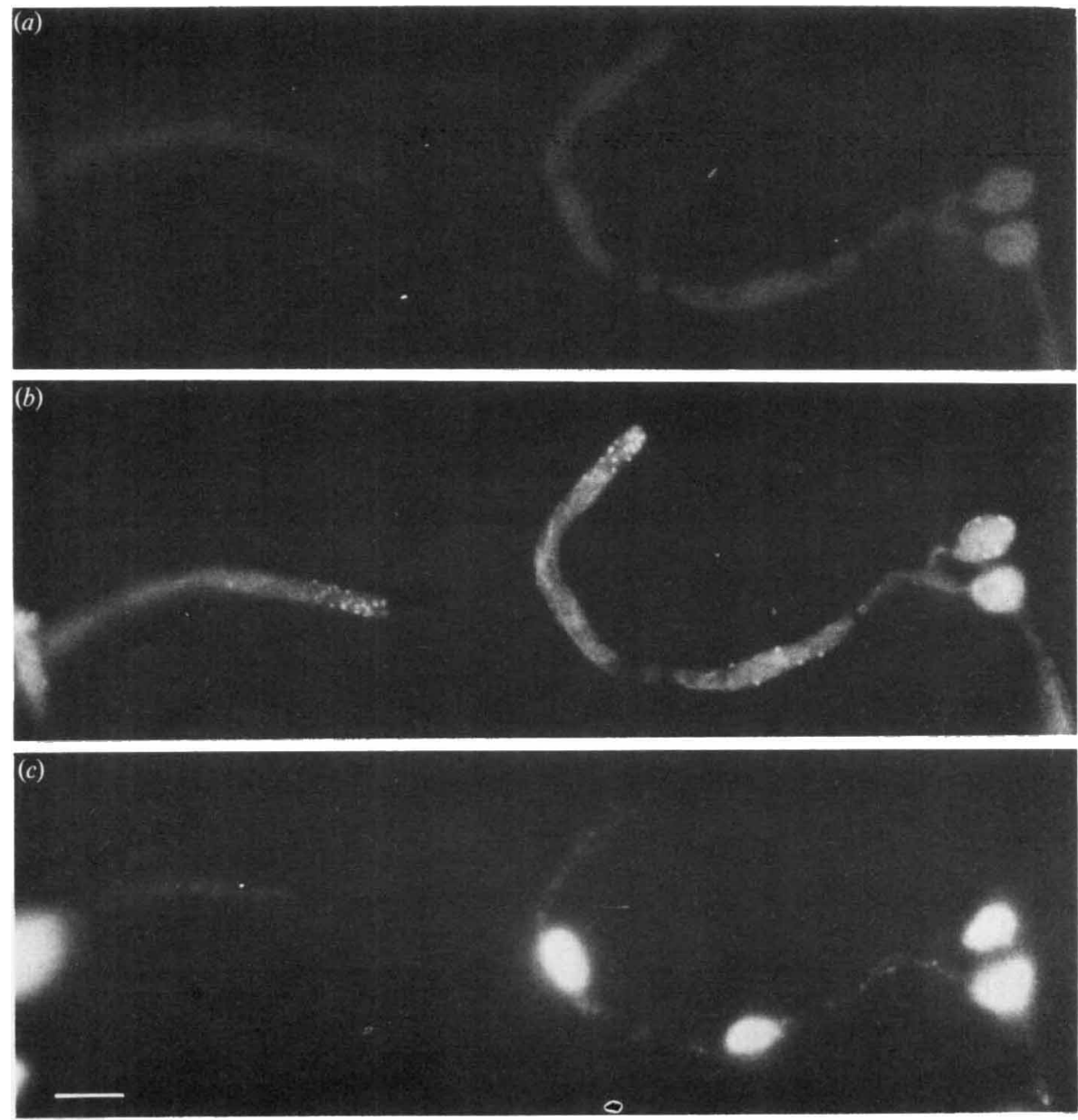

Fig. 4 

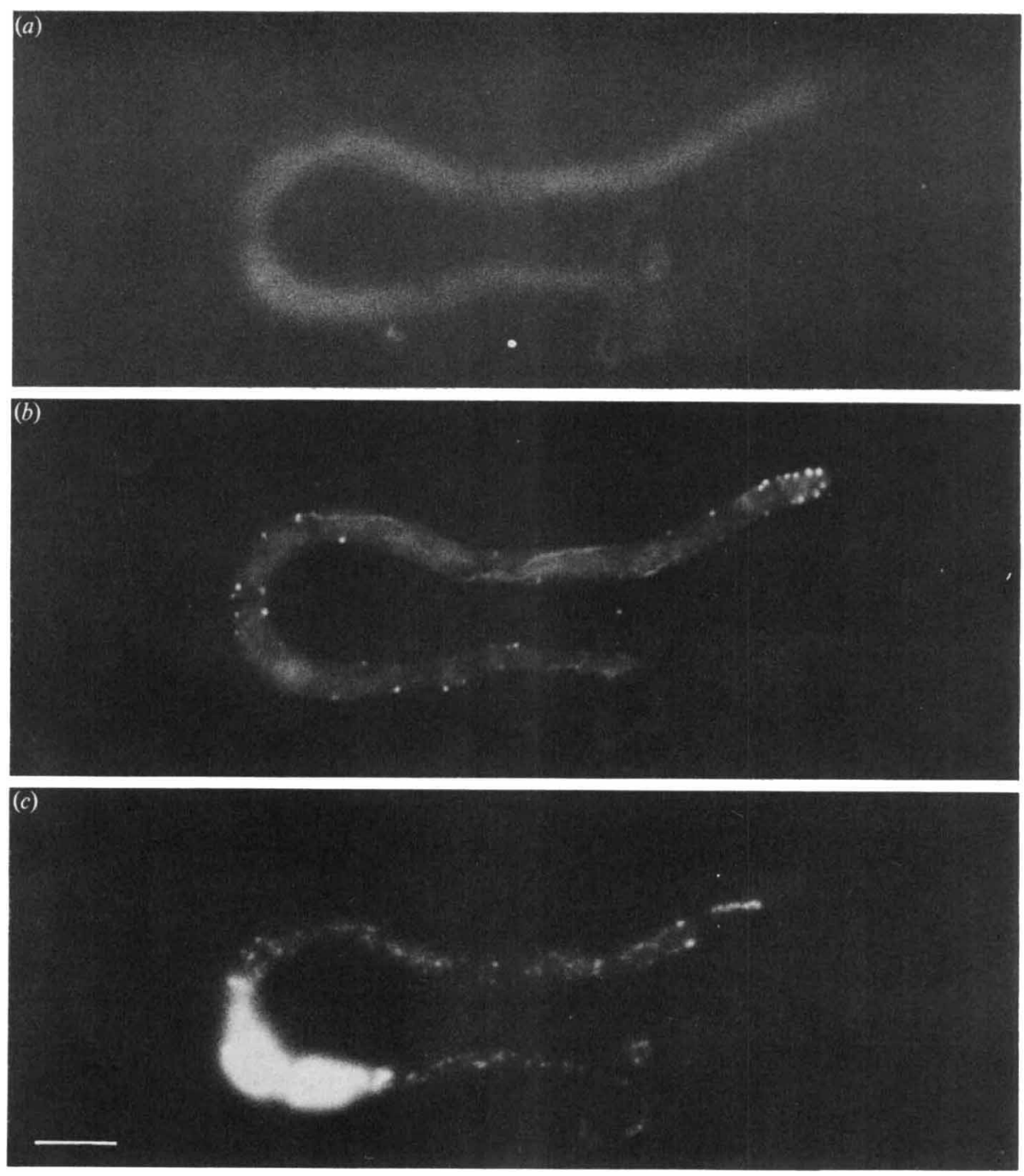

Fig. 5. Triple staining of nocodazole-treated hyphal cells of $C$. albicans IFM 40009. Cells were fixed after $3 \mathrm{~h}$ incubation with nocodazole $\left(20 \mu \mathrm{g} \mathrm{ml}^{-1}\right)$ in HFM7 medium. (a) Staining with anti-yeast-tubulin antibody and FITC-conjugated secondary antibody; (b) staining with Rh-phalloidin; $(c)$ staining with DAPI. Microtubules disappeared $(a)$ but the localization of actin granules and microfilaments $(b)$ was the same as in control cells. Nuclear division was inhibited $(c)$. Bar, $5 \mu \mathrm{m}$.

stopped and lateral buds were formed, but buds were not formed at the cell tip (Fig. $8 b$ ). Third, elongation of the apical cell was inhibited and the mother cell, but not the apical cell itself, produced lateral buds (Fig. $8 c$ ). Thus CIPC $\left(100 \mu \mathrm{g} \mathrm{ml}^{-1}\right)$ inhibited elongation of the apical cell, but permitted bud formation.

\section{Effect of CIPC on distribution of microtubules,} microfilaments and actin granules

A high concentration $\left(200 \mu \mathrm{g} \mathrm{ml}^{-1}\right)$ of CIPC inhibited localization of actin granules and destroyed microtubules. When CIPC was added at $100 \mu \mathrm{g} \mathrm{ml}^{-1}$, cytoplasmic microtubules were observed (Fig. 9a), but localization of actin granules was not observed at the tips of apical cells (Fig. 9b). Actin granules were found at the budding sites (Fig. 9b). This distribution of actin granules was the same as in budding yeast, but different from that in control hyphae. Microfilaments were not observed in either the tips or the cytoplasm of the apical cells after 30 and $180 \mathrm{~min}$ of incubation (Fig. $9 b$ ). Nuclei were located near the budding site (Fig. $9 \mathrm{c}$ ). Results are shown for strain IFM 40009. The same results were obtained with the other strains tested (see Methods).

Elongation of apical cell tips continued in the absence of visible microtubules. However, when microfilaments were depolymerized and actin granules were dispersed from cell tips, elongation of apical cells was inhibited. A cluster of actin granules was always observed at sites of 


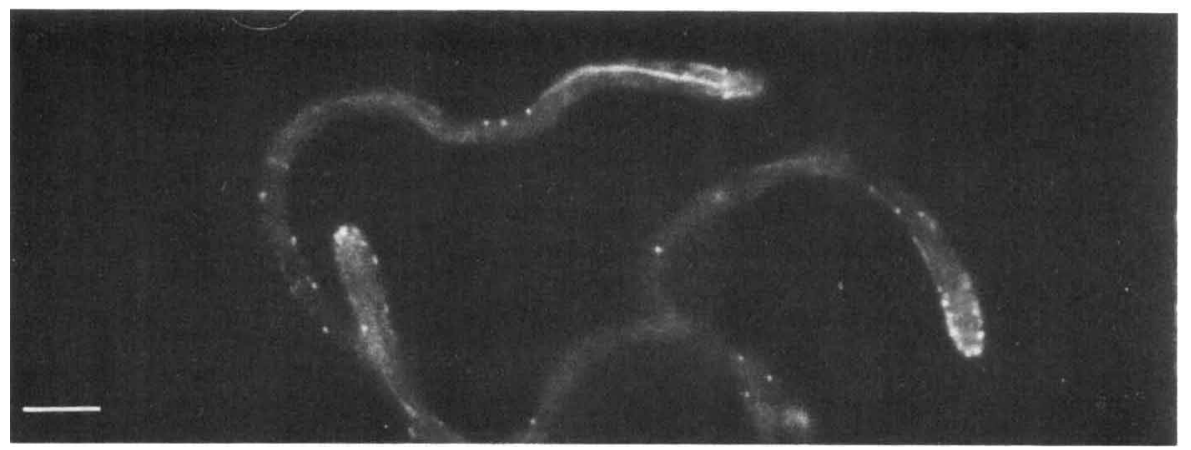

Fig. 6. Rh-phalloidin staining of nocodazole-treated hyphal cells of C. albicans IFM 40009. Cells were fixed after $3 \mathrm{~h}$ incubation with nocodazole $\left(20 \mu \mathrm{g} \mathrm{ml}^{-1}\right)$ in HFM7 medium. Long microtubules and their connections with actin granules were observed. Bar, $5 \mu \mathrm{m}$.
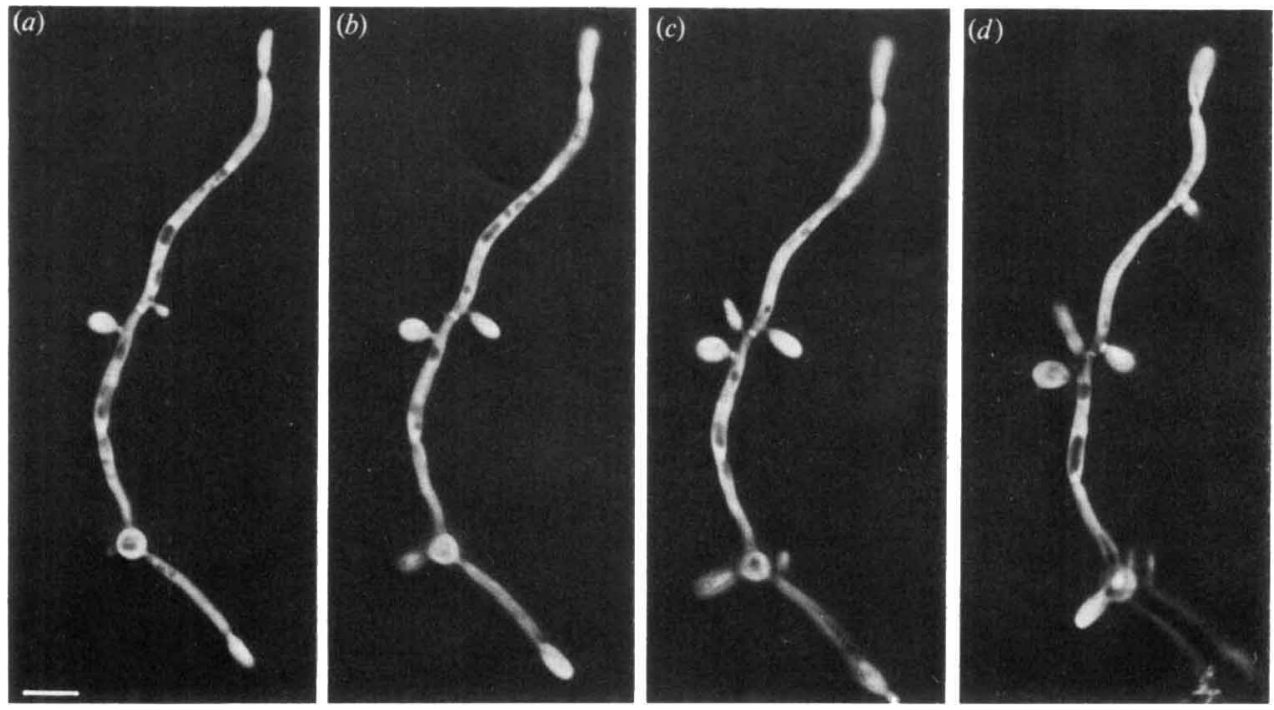

Fig. 7. Time-lapse microphotographs of cells of $C$. albicans IFM 40009 treated with CIPC $\left(100 \mu \mathrm{g} \mathrm{ml}^{-1}\right)$ in HFM7 medium. The time interval was $30 \mathrm{~min}$. The growth form changed from hyphal to yeast-like. Bar, $10 \mu \mathrm{m}$.
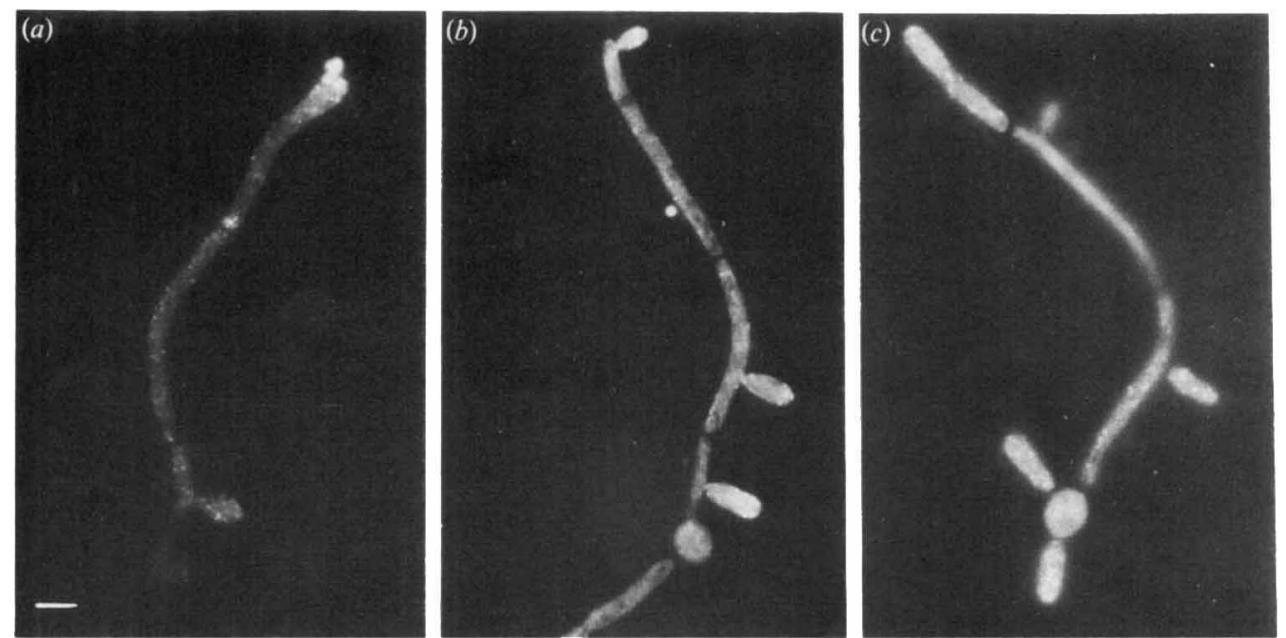

Fig. 8. Three patterns of growth inhibition of apical cells of $C$. albicans IFM 40009 treated with CIPC $\left(100 \mu \mathrm{g} \mathrm{ml} \mathrm{l}^{-1}\right)$ in $\mathrm{HFM} 7 \mathrm{medium}^{-}$ (a) Elongation of the apical cell was terminated and a bud was formed at the cell tip. (b) Elongation of the apical cell was terminated and lateral buds were formed; buds were not formed at the cell tip. (c) Elongation of the apical cell was terminated. The apical cell did not multiply, but the mother cell formed lateral buds. Bar, $5 \mu \mathrm{m}$. 

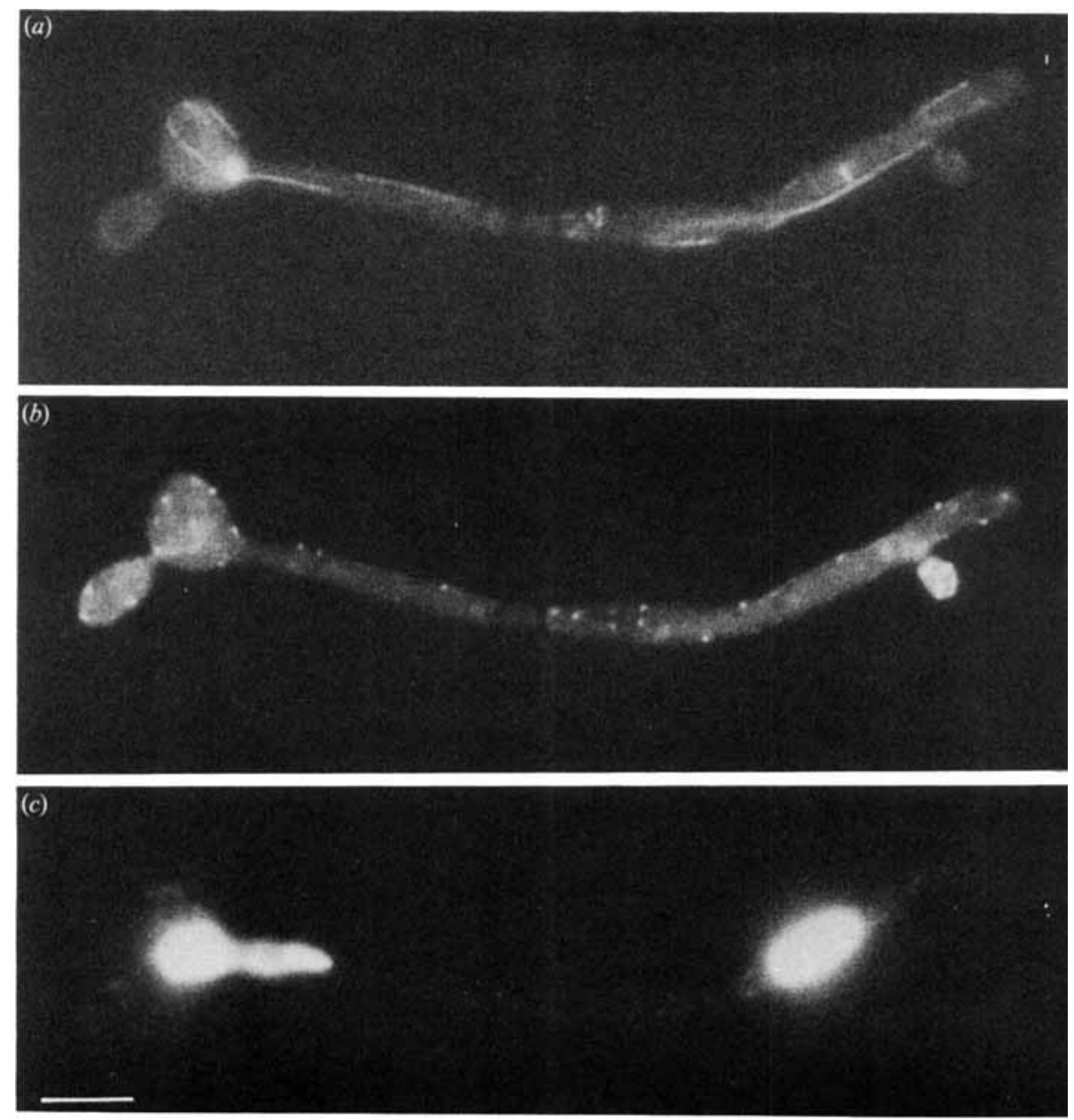

Fig. 9. Photomicrographs of cells treated with CIPC $\left(100 \mu \mathrm{g} \mathrm{ml}^{-1}\right)$. C. albicans IFM 40009 was incubated in HFM7 for $3.5 \mathrm{~h}$ and then CIPC was added. After further incubation for $3 \mathrm{~h}$, cells were fixed and triple stained. (a) Staining with anti-yeast-tubulin antibody and FITC-conjugated secondary antibody; $(b)$ staining with Rh-phalloidin; (c) staining with DAPI. Microtubules did not disappear in CIPC-treated hyphae. However, actin granules did not localize in the cell tips. Bar, $5 \mu \mathrm{m}$.

cell wall synthesis, i.e. the cell tip, the septum and the lateral bud.

\section{Discussion}

Our observations suggest that cytoplasmic microtubules are not essential for the elongation of filamentous cell tips but that microfilaments are essential for this process, perhaps via the localization of actin granules in the tips of elongating cells. This differs from previous reports which have shown that microtubules are related to tip growth and morphogenesis in Fusarium acuminatum (Howard \& Aist, 1980), Neurospora crassa (Caesar et al., 1988), Physcomitrella patens (Doonan et al., 1988) and Schizosaccharomyces pombe (Hagan \& Hyams, 1988). However, it has been reported that cytoplasmic micro- tubules are apparently not essential for the establishment of cell polarity and localization of cell-surface growth in Saccharomyces cerevisiae (Jacobs et al., 1988); these results are comparable with our results with regard to functions of microtubules and effects of nocodazole in C. albicans.

These reports (Howard \& Aist, 1980; Caesar et al., 1988; Doonan et al., 1988; Hagan \& Hyams, 1988; Jacobs et al., 1988) did not refer either to microfilaments or to inhibited organization of microfilaments. Our demonstration of microfilaments and their role in elongation was made possible by the use of $5 \% \mathrm{DMSO}$ in preparing samples for microscopy. Microfilaments, particularly the long microfilaments, are easily perturbed by fixation treatment. We used $4 \%$ paraformaldehyde containing 5\% DMSO for fixation, and the subsequent treatment buffers contained 5\% DMSO in order to 
obtain unperturbed distribution of microfilaments after fixation. Heath (1987) found that peripheral plaques or spots of actin were absent in growing hyphal tips of the fungus Saprolegnia ferax but they appeared when phosphate-buffered saline was used in prefixative treatments. These plaques or spots were irregular in shape and randomly distributed, and were considered to be artifacts. We observed regularly shaped and distributed actin granules in C. albicans using PBS ( $\mathrm{pH} \mathrm{8.2),}$ containing $5 \%$ DMSO; therefore we consider the plaques and spots observed by Heath (1987) to be different from the actin granules observed by us.

Nocodazole treatment caused microtubules to disappear, but it had no effect on the amount or distribution of microfilaments and actin granules. Fragmented microfilaments connected with actin granules were concentrated in the tips of cells, as in untreated controls. These observations are consistent with those of Anderson \& Soll (1986) for C. albicans, and with those of Jacobs et al. (1988) for Saccharomyces cerevisiae. A high concentration $\left(200 \mu \mathrm{g} \mathrm{m}^{-1}\right)$ of CIPC inhibited microtubule and microfilament organization in $C$. albicans, while a lower concentration $\left(100 \mu \mathrm{g} \mathrm{ml}^{-1}\right)$ permitted nuclear division, arrested apical cell elongation and, most strikingly, converted filamentous growth into yeast growth. Our findings support those of Oliver et al. (1978) regarding the inhibitory effect of CIPC on microfilament and microtubule organization. In the presence of $100 \mu \mathrm{g}$ CIPC $\mathrm{ml}^{-1}$, microtubules could be observed in the filamentous cells. However, microfilaments were not observed and actin granules did not localize in the tips of filamentous cells but were distributed throughout the cytoplasm.

The actin granules stained with Rh-phalloidin were always observed at the site of cell wall synthesis, that is, the cell tip or septum. During yeast growth, actin granules were localized in the budding site and the septum-forming site but were more evenly distributed in mature cells. Localization of the actin granules, which are probably involved in cell wall synthesis, was supported by a network of short microfilaments and long microfilaments.

Our results show that microfilaments are important in the elongation of apical cells (and thus the ability to form hyphae), but that microtubules are not essential for this process. We believe that our findings are of significance for the study of dimorphism in C. albicans and other fungi.

\section{References}

Adams, A. E. M. \& Pringle, J. R. (1984). Relationship of actin and tubulin distribution to bud growth in wild-type and morphogeneticmutant Saccharomyces cerevisiae. Journal of Cell Biology 98, 934-945.
Anderson, J. M. \& Soll, D. R. (1986). Differences in actin localization during bud and hypha formation in the yeast Candida albicans. Journal of General Microbiology 132, 2035-2047.

BARTON, R. \& GULL, K. (1988). Variation in cytoplasmic microtubule organization and spindle length between the two forms of the dimorphic fungus Candida albicans. Journal of Cell Science 91, 211220.

BYERS, B. \& GOETSCH, L. (1975). Behavior of spindles and spindle plaques in the cell cycle and conjugation of Saccharomyces cerevisiae. Journal of Bacteriology 124, 511-523.

Caesar, T. C., Rossier, C., Barja, F., Turian, G. \& Roos, U. (1988). Induction of multiple germ tubes in Neurospora crassa by anti-tubulin agents. European Journal of Cell Biology 46, 68-79.

Davidse, L. C. \& FLACH, W. (1977). Differential binding of methyl benzimidazol-2-yl carbamate to fungal tubulin as a mechanism of resistance to this antimitotic agent in mutant strains of Aspergillus nidulans. Journal of Cell Biology 72, 174-193.

De Brabander, M. J., Van de Veire, R. M. L., Aerts, F. E. M., BORGER, M. \& JANSSEN, P. J. (1976). The effects of methyl[5-(2thienylcarbonyl)-1H-benzimidazol-2-yl]carbamate (R 17934; NSC 238159), a new synthetic antitumoral drug interfering with microtubules, on mammalian cells cultured in vitro. Cancer Research 36, 905-916.

Doonan, J. H., Cove, D. J. \& Lloyd, C. W. (1988). Microtubules and microfilaments in tip growth: evidence that microtubules impose polarity on protonemal growth in Physcomitrella patens. Journal of Cell Science 89, 533-540.

Hagan, I. M. \& Hyams, J. S. (1988). The use of cell division cycle mutants to investigate the control of microtubule distribution in the fission yeast Schizosaccharomyces pombe. Journal of Cell Science 89, 343-357.

Heath, I. B. (1987). Preservation of a labile cortical array of actin filaments in growing hyphal tips of the fungus Saprolegnia ferax. European Journal of Cell Biology 44, 10-16.

Hoch, H. C. \& Staples, R. C. (1985). The microtubule cytoskeleton in hyphae of Uromyces phaseoli germlings: its relationship to the region of nucleation and to the F-actin cytoskeleton. Protoplasma 124, 112 122 .

Hoebeke, J., Van Nijen, G. \& De Brabander, M. (1976). Interaction of oncodazole (R17934), a new antitumoral drug, with rat brain tubulin. Biochemical and Biophysical Research Communications 69, 319-324.

Howard, R. H. \& AIST, J. R. (1980). Cytoplasmic microtubules and fungal morphogenesis: ultrastructural effects of methyl benzimidazole-2-yl carbamate determined by freeze-substitution of hyphal tip cells. Journal of Cell Biology 87, 55-64.

Jacobs, C. W., Adams, A. E. M., Szanizlo, P. J. \& Pringle, J. R. (1988). Functions of microtubules in the Saccharomyces cerevisiae cell cycle. Journal of Cell Biology 107, 1409-1426.

Kilmartin, J. V. \& Adams, A. E. M. (1984). Structural rearrangements of tubulin and actin during the cell cycle of the yeast Saccharomyces. Journal of Cell Biology 98, 922-933.

Marks, J., HaGan, I. M. \& Hyams, J. S. (1986). Growth polarity and cytokinesis in fission yeast: the role of the cytoskeleton. Journal of Cell Science, Suppl. 5, 229-241.

Novick, P. \& BotsteIN, D. (1985). Phenotypic analysis of temperaturesensitive yeast actin mutants. Cell 40, 406-416.

Oliver, J. M., Karawiec, J. A. \& Berlin, R. D. (1978). A carbamate herbicide causes microtubule and microfilament disruption and nuclear fragmentation in fibroblasts. Experimental Cell Research 116, 229-237.

Quinlan, R. A., Pogson, C. I. \& Gull, K. (1980). The influence of the microtubule inhibitor, methyl benzimidazol-2-yl-carbamate (MBC) on nuclear division and the cell cycle in Sacharomyces cerevisiae. Journal of Cell Science 46, 341-352.

That, T. C. C., Rossier, C., Barja, F., Turian, G. \& Roos, U. (1988). Induction of multiple germ tubes in Neurospora crassa by antitubulin agents. European Journal of Cell Biology 46, 68-79.

YoKoYAma, K. \& TAKEO, K. (1983). Differences of asymmetrical division between the pseudomycelial and yeast forms of Candida albicans and their effect on multiplication. Archives of Microbiology 134, 251-253. 